\title{
Millennial paleotsunami history at Minna Island, southern Ryukyu Islands, Japan
}

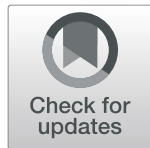

Ryosuke Fujita ${ }^{1 *}$, Kazuhisa Goto ${ }^{2,3}$, Yasufumi Iryu ${ }^{1}$ and Tomoya Abe ${ }^{4}$

\begin{abstract}
Huge tsunami waves have repeatedly bombarded the southern end of the Ryukyu Islands (Miyako and Yaeyama Islands, southwestern Japan) at several-hundred-year intervals. Therefore, clarifying the islands' paleotsunami history is important for risk assessment. Nevertheless, discrepancies of paleotsunami histories exist among regional studies of tsunami boulders and sandy tsunami deposits. Radiocarbon ages of tsunami boulders indicate that tsunami events of the last 2400 years have occurred every 150-400 years, most recently the historical 1771 Meiwa tsunami. Sandy tsunami deposits at Yaeyama Islands show that four tsunami events of the last 2000 years struck the islands at approximately 600 -year intervals. Sandy tsunami deposits of the Miyako Islands have been studied only rarely. Therefore, studying sandy tsunami deposits in the Miyako Islands is crucially important for clarifying the paleotsunami history of this region. We conducted a trench survey on Minna Island, located among the westernmost Miyako Islands, which revealed two sandy tsunami deposits under a coral tsunami boulder transported by the 1771 tsunami. The upper tsunami deposit was likely deposited by the 1771 tsunami, as inferred from stratigraphic correlation to the tsunami boulder. However, the lower tsunami deposit was probably deposited 700-1000 years ago, which is consistent with the age range of the paleotsunami reported for Yaeyama Islands. Because sandy tsunami deposits found in this and earlier studies are thick and deposited at high elevation and far inland, these are useful markers of large tsunami events similar to the 1771 event. However, the reported tsunami boulders of various sizes are deposited along the coast and reefs: they can be formed not only by large tsunami events but also by small ones. It is noteworthy that each tsunami deposit is coarse and thick $(40-48 \mathrm{~cm}$ ) relative to the island elevation (about $12 \mathrm{~m}$ maximum, $7 \mathrm{~m}$ above the mean sea level at the study site). By assuming that tsunamis have affected this region repeatedly during the past few thousand years at around 600-year intervals, tsunamis might have been important geomorphic agents for building up small reef-surrounded islands such as Minna Island.
\end{abstract}

Keywords: 1771 Meiwa tsunami, Geomorphology, Minna Island, Paleotsunami history, Radiocarbon age, Tsunami boulder, Tsunami deposit

\section{Introduction}

Understanding paleotsunami history based on the geological record is important for long-term tsunami risk assessment. Meter-sized boulders are one such example (e.g., Goto et al. 2010a). Many boulders transported and deposited by paleotsunamis are observed along the shorelines of the Miyako and Yaeyama Islands of the southern Ryukyu Islands in southwestern Japan (Fig. 1,

\footnotetext{
* Correspondence: r.trackandfield@gmail.com

${ }^{1}$ Department of Earth Science, Graduate School of Tohoku University,

Aramaki-Aza-aoba, 6-3, Aoba-ku, Sendai 980-8578, Japan

Full list of author information is available at the end of the article
}

Goto et al. 2010a, b, 2019). Some of these boulders, called tsunami boulders, comprise coral rocks (Kawana and Nakata 1994; Omoto 2012; Araoka et al. 2013). From the radiocarbon ages of tsunami boulders, Araoka et al. (2013) inferred statistically that eight tsunamis had struck these islands at 150-400year intervals during the last 2400 years. The latest event was the Meiwa tsunami in 1771. Numerical analyses (Hisamatsu et al. 2014) and residual magnetism measurements of tsunami boulders (Sato et al. 2014) further indicated that more than three huge tsunamis as large as the 1771 Meiwa tsunami, 


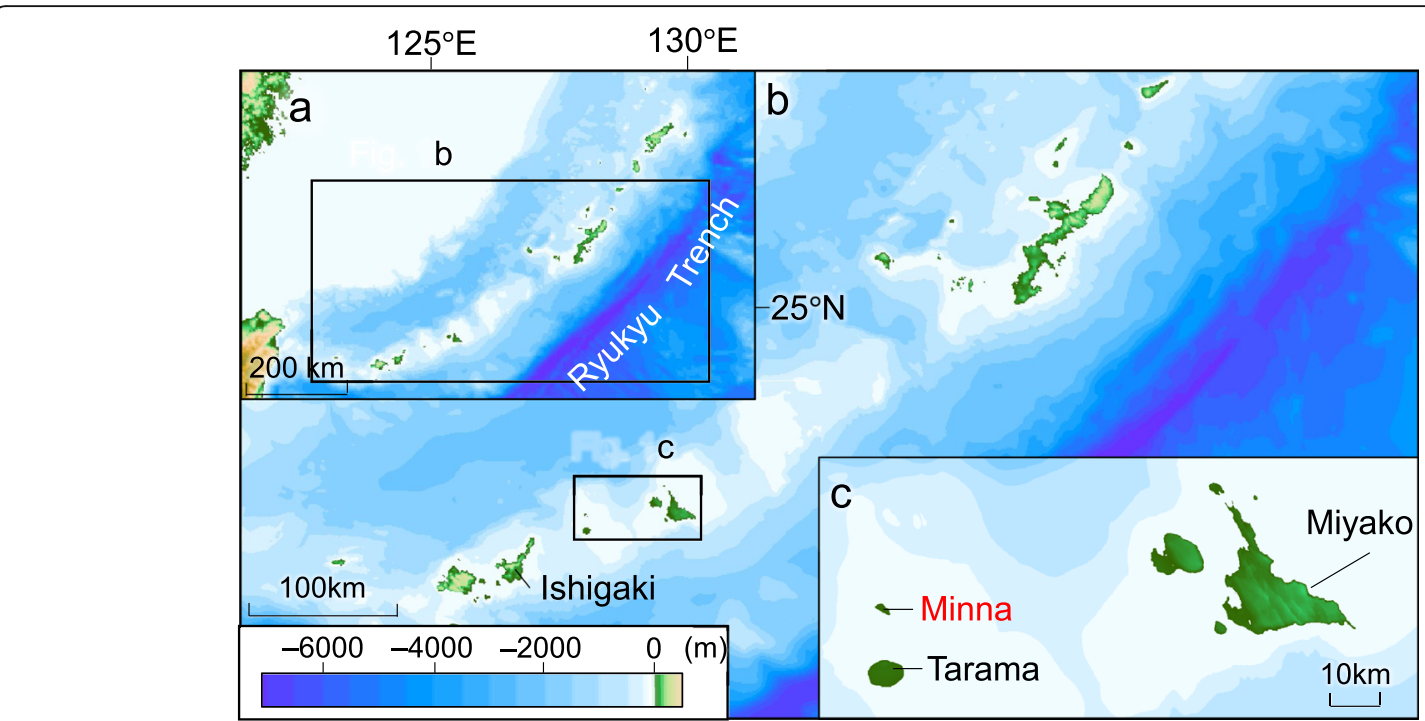

Fig. 1 Study area maps: a Ryukyu arc and trench; b Miyako Islands and Yaeyama Islands; c Miyako Islands

including the 1771 event, are likely to have affected to the Miyako and Yaeyama Islands during the last 2000 years.

Historical and geological records of the 1771 Meiwa tsunami indicate that the maximum runup height was about $30 \mathrm{~m}$ along the eastern coast of Ishigaki Island and that 12,000 people were killed (e.g., Goto et al. 2010a, 2012a). Although many historical and geological lines of evidence remain in the Miyako and Yaeyama Islands (Araoka et al. 2010; Goto et al. 2010a, 2012a), the tsunami source remains controversial. The hypothetical sources include (1) an interplate earthquake plus submarine landslide (Imamura et al. 2008), (2) tsunami earthquake along the Ryukyu trench (Nakamura 2009), and (3) a single massive landslide near the trench axis (Okamura et al. 2018).

Table 1 Representative paleotsunami history in Miyako and Yaeyama Islands

\begin{tabular}{|c|c|c|c|c|}
\hline Study & $\begin{array}{l}\text { Recurrence } \\
\text { (years) }\end{array}$ & $\begin{array}{l}\text { Tsunami age } \\
\text { (cal years BP) }\end{array}$ & Study area & $\begin{array}{l}\text { Type of tsunami } \\
\text { deposits }\end{array}$ \\
\hline Araoka et al. (2013) & $150-400$ & $\begin{array}{l}250-50 \\
450-250 \\
650-450 \\
1050-650 \\
1250-1050 \\
1550-1250 \\
1850-1550 \\
2300-2050\end{array}$ & $\begin{array}{l}\text { Miyako Islands } \\
\text { Yaeyama Islands }\end{array}$ & Boulder \\
\hline Kawana and Nakata (1994) & $500-1000$ & $\begin{array}{l}150 \\
600-450 \\
1150-950 \\
2450-1900 \\
3700 \\
4400-4300\end{array}$ & Miyako Islands & $\begin{array}{l}\text { Boulder } \\
\text { Sand }\end{array}$ \\
\hline Omoto (2012) & - & A.D. 1771-B.C. 252 & Miyako Islands & Boulder \\
\hline $\begin{array}{l}\text { Okinawa Prefecture Gusukube Town } \\
\text { Board of Education (2004) }\end{array}$ & - & A.D. 1771 & Miyako Islands & Sand \\
\hline Kugai (2011) & - & A.D. 1771 & Miyako Islands & Sand \\
\hline Nakaza et al. (2013) & & A.D. 1771 & Miyako Islands & Sand \\
\hline Ando et al. (2018) & 630 & $\begin{array}{l}248 \\
920-620 \\
1670-1250 \\
2700-1670\end{array}$ & Yaeyama Islands & \\
\hline $\begin{array}{l}\text { Yamamoto (2008) and Yamamoto } \\
\text { et al. (2009) }\end{array}$ & - & $750-200$ & Yaeyama Islands & $\begin{array}{l}\text { Boulder } \\
\text { Sand }\end{array}$ \\
\hline
\end{tabular}


Although sandy tsunami deposits are used frequently to elucidate the paleotsunami histories along the coast of Japan (e.g., Minoura et al. 2001; Ishimura and Miyauchi 2015; Kitamura 2016; Inoue et al. 2017; Shimada et al. 2019), few have been reported from the Miyako and Yaeyama Islands because of the small number of surveys (Table 1). Detailed paleotsunami studies of the islands conducted by Ando et al. (2018) and by Kitamura et al. (2018a) have specifically examined sandy deposits.

Ando et al. (2018) identified three sandy tsunami deposits (T-I, T-II, and T-IV) and tsunami boulders (T-III that located stratigraphically between T-II and T-IV) from an excavated trench at a ranch on the east coast of Ishigaki Island, Yaeyama Islands. These deposits (T-I to IV) were deposited respectively in AD 1771 (Meiwa tsunami), at 920-620 cal. year BP, at 1670-1250 cal. year $\mathrm{BP}$, and at $2700-2280$ to $1670-1250 \mathrm{cal}$. year BP. Ando et al. (2018) interpreted that the tsunami events which formed deposits T-II and IV were of similar size to the 1771 tsunami. Kitamura et al. (2018b) used molluscan assemblages in sandy tsunami deposits at the artificial trench reported by Ando et al. (2018). They assessed the influences of local topographic features on the local tsunami size. They also estimated the local sizes of two tsunamis that occurred before the 1771 event as being equivalent to the 1771 tsunami.

Results presented in Table 1 present discrepancies of paleotsunami histories that exist between studies of tsunami boulders and sandy tsunami deposits in this region. The tsunami recurrence interval estimated from tsunami boulders is far shorter than that estimated from sandy tsunami deposits. The dearth of evidence from the Miyako Islands prevents elucidation of the paleotsunami history in this region. Further study of sandy tsunami deposits is important to resolve this discrepancy. As described herein, we conducted a paleotsunami survey in Minna Island of the Miyako Islands (Figs. 1 and 2). According to historical documentation, the 1771 Meiwa tsunami completely inundated this island (Kato 1989), which is located far from the estimated tsunami source (i.e., southeast of Ishigaki Island). Therefore, paleotsunami evidence of the island is expected to be a key to ascertaining whether powerful tsunami events equivalent to the 1771 Meiwa tsunami occurred repeatedly and struck the South Ryukyu Islands.

\section{Geological setting}

Minna Island, located on the western end of Miyako Islands, $7 \mathrm{~km}$ north of Tarama Island (Fig. 1c), is about

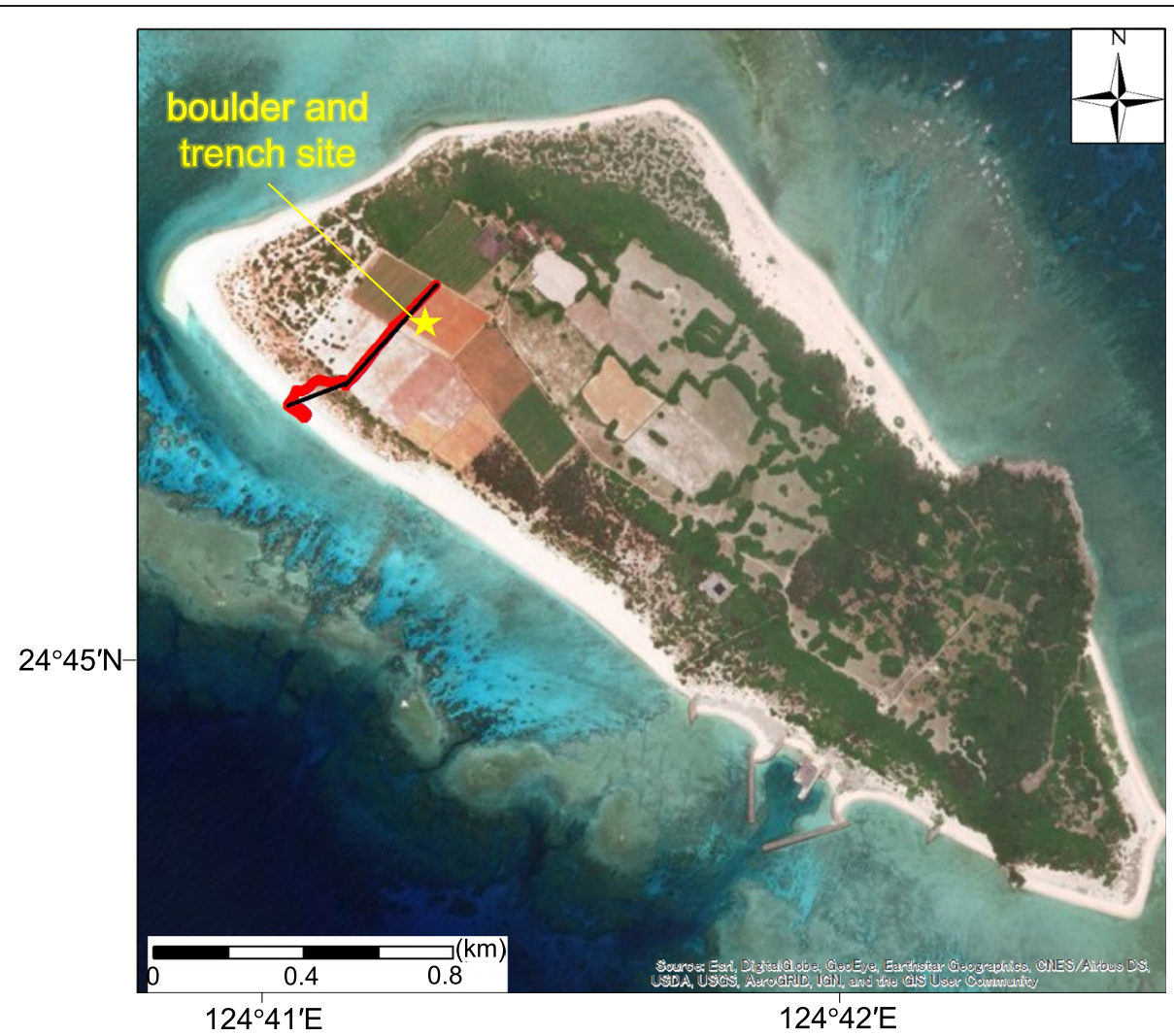

Fig. 2 Aerial photograph of Minna Island: the red line shows an actual route of Ground-Penetrating Rader (GPR) survey; the black line shows the projected line used to depict cross-sectional subbottom profile in Fig. 3 
$2.5 \mathrm{~km}^{2}$, with approximately $12 \mathrm{~m}$ above mean sea level (amsl) maximum elevation. Coral reefs with average width of approximately $500 \mathrm{~m}$ surround the whole island (Fig. 2a). Approximately $70 \%$ of the island has elevation lower than $5 \mathrm{~m}$ amsl. Today, most lowlands are used as pastureland (Yazaki 1977). The Ryukyu Groups consist of reef limestone (Iryu et al. 2006) with tens of meters thickness, constituting the basement rock of this island. The island is covered with dune sand and 7-11 m thick soil (Yazaki 1977).

An emerged shoreline, indicated by erosional notches, benches, and beach rocks, occurs at an elevation of 1.5 $\mathrm{m}$ along the coast of Tarama Island, immediately south of Minna Island (Fig. 1). Based on ${ }^{14} \mathrm{C}$ dates of a coral and a tridacnine shell, Pirazzoli et al. (1984) reported continuous and gradual sea-level fall for the last 4000 years. Similarly, based on ${ }^{14} \mathrm{C}$ dates of corals and coralline algae, along with geomorphological observations, Konishi and Matsuda (1980) showed that the presentday reef crest of Kabira Reef, Ishigaki Island (Fig. 1), exposing $60 \mathrm{~cm}$ above the mean low tide level represent a relic of a salient ridge grown between 1500 and 3000 year BP, when the sea level stood at least $1.5 \mathrm{~m}$ higher than at present. This view was supported by evidence from Yamano et al. (2001), who studied the anatomy of Kabira Reef, showing that a stable sea level between 6000 and 2000 year BP was followed by a relative sealevel fall because of tectonic uplift associated with the tilting of Ishigaki Island (Kawana 1986, 1989). This tectonic movement occurred at 1700-2700 year BP (centered at 2000-2400 year BP) throughout the Ryukyu Islands.

We consider that Minna and Tarama islands have been uplifted since the late Middle Pleistocene, as indicated by the occurrence of upper Middle and upper Pleistocene reef limestones offlapping the main body of the Ryukyu Group (Iryu et al. 2006). The occurrence of the reef crest, subaerially exposed at the low tide, suggests tectonic uplift occurring in these islands at approximately $2000-2400$ year BP, as reported throughout the Ryukyu Islands.

A 33-ton tsunami boulder made of Porites sp. is located at elevation of $7 \mathrm{~m}$ amsl and $350 \mathrm{~m}$ inland from the present beach inferred as being of 1771 Meiwa tsunami origin based on radiocarbon dating results (AD 1515-1814 (2б); Kato 2000; Goto et al. 2010c). Although the ground surface of this island might have been disturbed to make pastureland, presence of the 1771 Meiwa tsunami boulder suggests that at least the ground beneath the boulder has not been disturbed by human activities since the 1771 tsunami. Recent studies conducted after the 2011 Tohoku-oki tsunami revealed that tsunami-transported sand layers are usually formed below the boulder deposits because sands are moved and deposited faster than the boulders (Goto et al. 2012b; Yamada et al. 2014), although this is not always the case (e.g., Yawsangratt et al. 2009). Therefore, sandy deposits can be expected to have originated by the 1771 Meiwa tsunami or older events are preserved below this boulder. We therefore decided to dig a trench immediately beneath this boulder.

\section{Methods/experimental}

A field survey was undertaken during 18-22 April 2017. We first excavated a $115 \mathrm{~cm}$-deep trench beneath the boulder. After description, we took 115 bulk sediment samples consecutively at $1 \mathrm{~cm}$ intervals. Additionally, we took marine shell and coral fragments from possible tsunami deposits for radiocarbon dating.

We also conducted a survey using ground-penetrating radar (GPR, SIR-3000; GSSI Inc., Nashua) along the route presented in Fig. 2b to identify cross-sectional subsurface structures. The data were processed by an analytical method using software (RADAN7; GSSI Inc., Nashua) referred from a report by Takeda et al. (2018). Using a "Pick" module with REFLEXW software (Sandmeier Geophysical Research, Karlsruhe), strong reflectors were detected from GPR profiles. Global Navigation Satellite System (GNSS) topographic measurement (Promark 120; Geosurf Corp., Tokyo) was also applied to produce a cross-sectional profile near the survey trench and to correct the elevation of the GPR profile.

For grain size analysis, we removed organic matter (e.g., plant roots) with $10 \mathrm{wt} \% \mathrm{H}_{2} \mathrm{O}_{2}$. Additionally, to investigate grain size composition and major components of sand grains at our study site, we removed the mud component $(<63 \mu \mathrm{m})$ by wet sieving. Grains generally of $>2 \mathrm{~mm}$ were removed by hand picking. Then, we measured the grain size distribution of residual samples using a settling tube method with STube software (Naruse 2005). Results were compiled using software (GMT5, SOEST; University of Hawaii) to estimate the grain size distribution with volume percentage. For peak splitting, the Gaussian distribution was applied to every peak graph using software (ORIGIN 2015; Origin Lab, Massachusetts). Although we removed mud and gravel components, a few might have been left in the residue. To illustrate vertical change of grain size distribution, we calculated statistical values (mean size, median size, and sorting) using data ranging from -1 to 4 phi, whereas data out of this range were not used. Mean and median grain sizes and sorting were calculated using the moment method (Folk 1966).

The tsunami deposit itself is usually a mixture of redeposited sediment from various sources. Therefore, radiocarbon dating is better conducted using organic matter in sediments immediately above and below the deposit (Sawai 2012). However, at our study site, this approach 
is not useful because the site is located in a subtropical region. Sediments above and below the possible tsunami deposit comprise sand-sized carbonate grains; moreover, they have been disturbed considerably by vegetation. The possible tsunami deposit in our site includes many coral and mollusk fragments. Therefore, some specimens which retain their original mineralogy and in which no diagenetic product (e.g., marine cements) is observed are highly likely to have been killed by the tsunami and therefore represent the tsunami age. We analyzed ages of such samples taken directly from the possible tsunami deposit.

Before ${ }^{14} \mathrm{C}$ dating, we checked whether samples retained the original mineralogical composition of marine shells or skeleton (aragonite), using X-ray diffraction (XRD) analysis with X'pert-MPD (PW3050; Philips Co., Amsterdam) X-ray diffractometry and using observation of coral skeletons and a marine shell done with scanning electron microscopy (SEM, VE-8800; Keyence Co., Osaka) at the Department of Earth Science, Graduate School of Science, Tohoku University. ${ }^{14} \mathrm{C}$ ages were measured using an accelerator mass spectrometer at Beta Analytic Inc. in Miami, USA. The Marine13 dataset (Reimer et al. 2013) with CALIB 7.1 software (Stuvier and Reimer, 1993; Stuiver et al. 2020) was adopted to calculate the calibrated ages. A local reservoir correction $(\Delta R=-36 \pm 78$; Hirabayashi et al. 2017) for the Central Ryukyus was used for this study.

\section{Results}

\subsection{Topography and GPR profile}

Figure 3a portrays a cross-sectional profile produced from GNSS and GPR profile measurements. From the beach to $100 \mathrm{~m}$ inland, the elevation increases steeply to $6.5 \mathrm{~m}$ amsl and forms sand dunes. Over $100 \mathrm{~m}$ from the

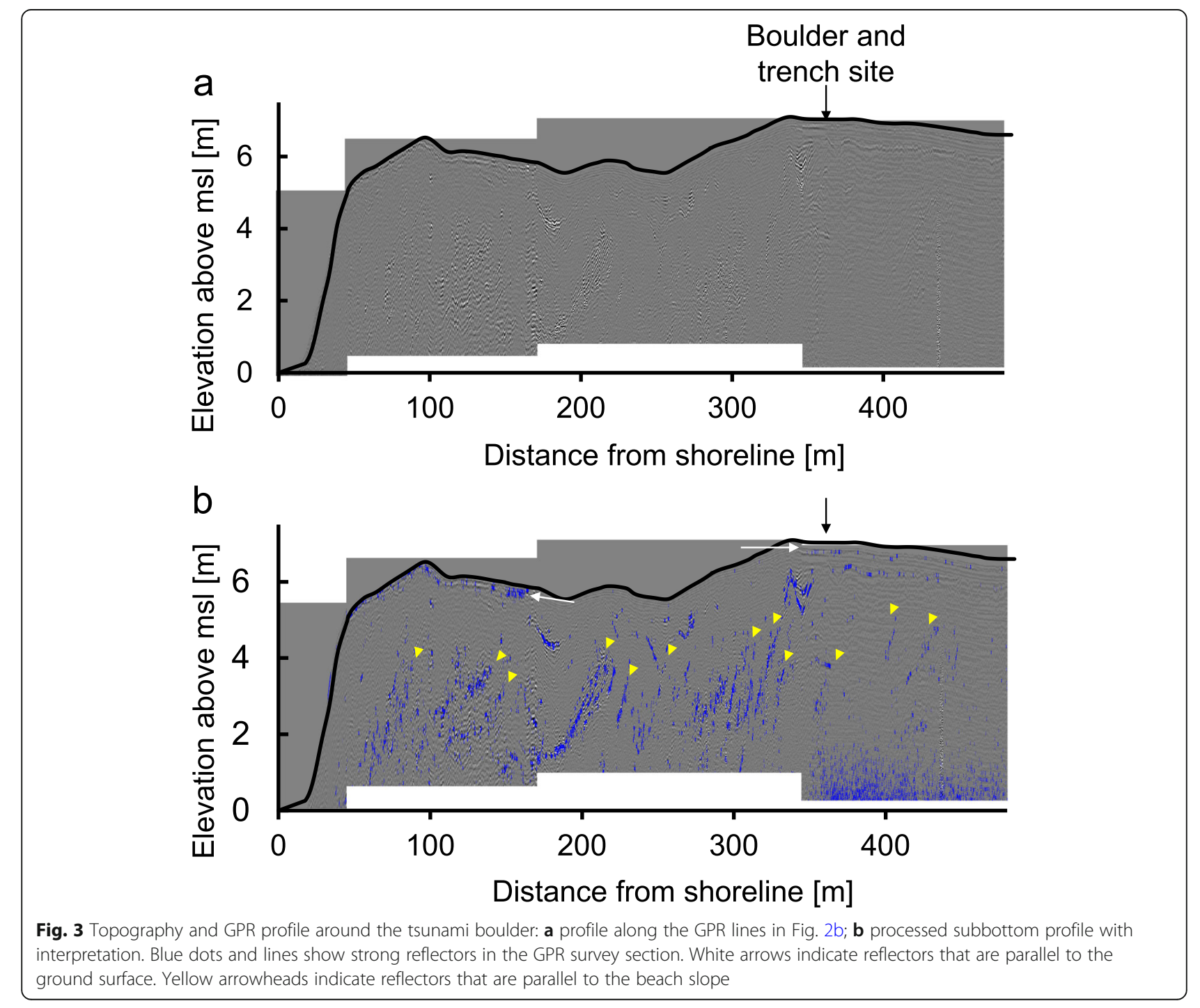


beach to the boulder/trench site, the elevation is roughly constant at about 5-7 m amsl.

A processed GPR profile (Fig. 3b) shows some clear successive reflectors. First, several reflectors that are parallel to the present beach slope are observed from 50 to $350 \mathrm{~m}$ from the beach. Another reflector, which is parallel to the ground surface, is also observed at about 50 $\mathrm{cm}$ below the ground from 50 to $150 \mathrm{~m}$ and from 350 to $500 \mathrm{~m}$ from the beach. A clear reflector expected to correspond to the boundary between the sand deposit and the underlying reef limestone was not detected up to 7 m depth.

\subsection{Trench description}

The 1771 Meiwa tsunami boulder at the trench site, which is $3.7 \mathrm{~m}$ long, $3.1 \mathrm{~m}$ width, and $2.3 \mathrm{~m}$ height (Fig. $4 \mathrm{a}$ ), is made of a massive coral of Porites sp. The present boulder orientation is similar to its original living position.
Based on the color and grain size, sediments in the $115 \mathrm{~cm}$ deep trench are classified into five layers from the bottom to the top (Figs. 4b-d and 5): layer 1 (L1, 0$27 \mathrm{~cm}$ above the trench bottom) consisting of dark brown medium-grained sand, layer 2 (L2, 27-60 cm above the trench bottom) of dark brown mediumgrained to coarse-grained sand, layer 3 (L3, 60-67 cm from the trench bottom) of dark brown medium-grained sand, layer 4 (L4, 67-95 cm from the trench bottom) of yellowish brown medium to very coarse sand, and layer 5 (L5, 95-115 cm from the trench bottom) of dark brown medium sand. The boundaries of the respective layers are generally clear. However, the boundary between L2 and L3 is not clearly visible to the naked eye while we established the boundary in the field based on the difference of grain size. The boulder is deposited directly on top of L4, whereas L5 is not observed immediately beneath the boulder (Fig. 4b, c). Visually,

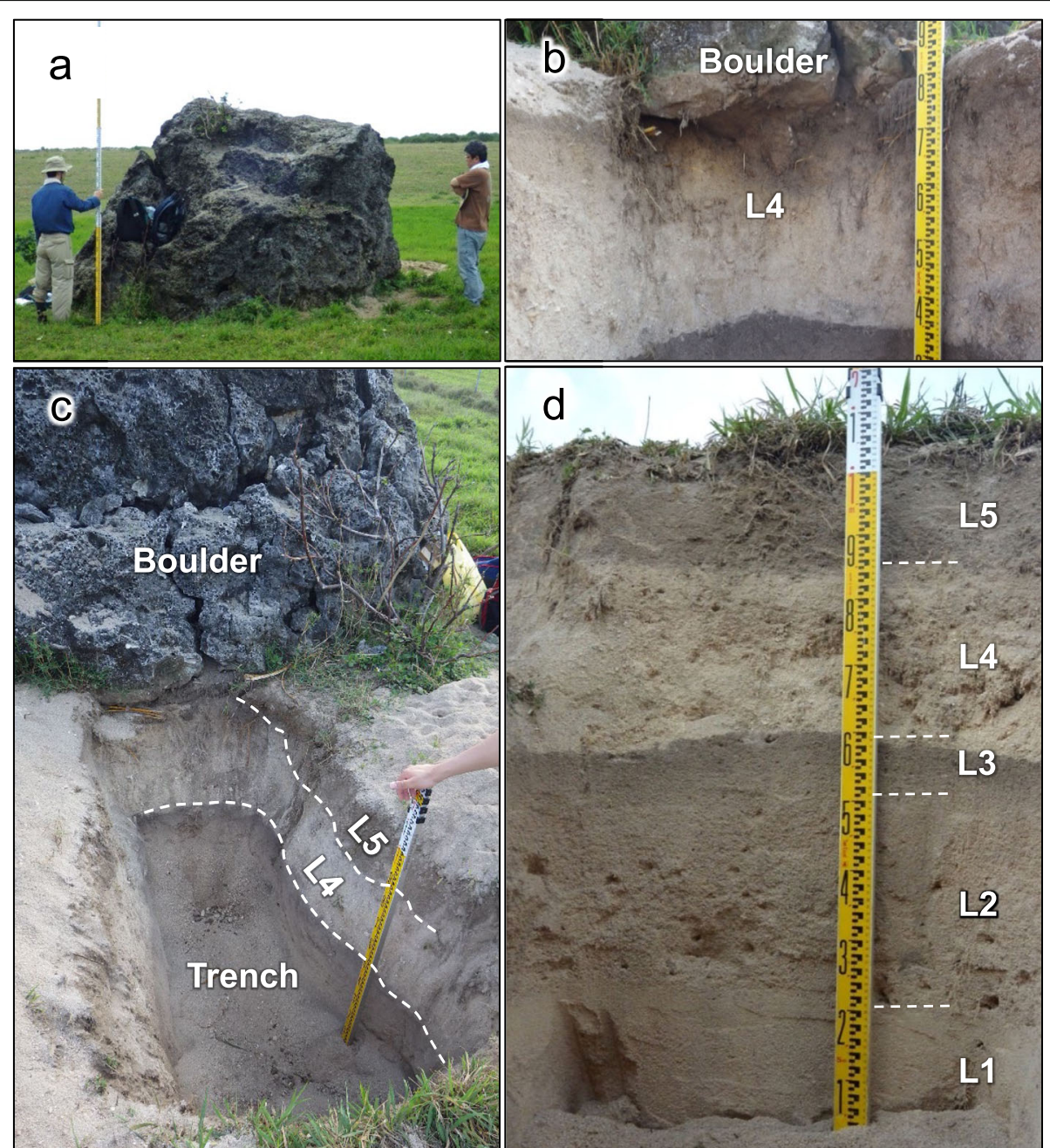

Fig. 4 Outcrop photographs: a tsunami boulder composed of Porites sp. at $7 \mathrm{~m}$ elevation; $\mathbf{b}$ trench below the boulder; $\mathbf{c}$ relation among the tsunami boulder, $L 4$ and $L 5$; $\mathbf{d}$ stratigraphy of the trench from $L 1$ to $L 5$. It is noteworthy that the boulder is deposited not on $L 5$, but on $L 4$ 


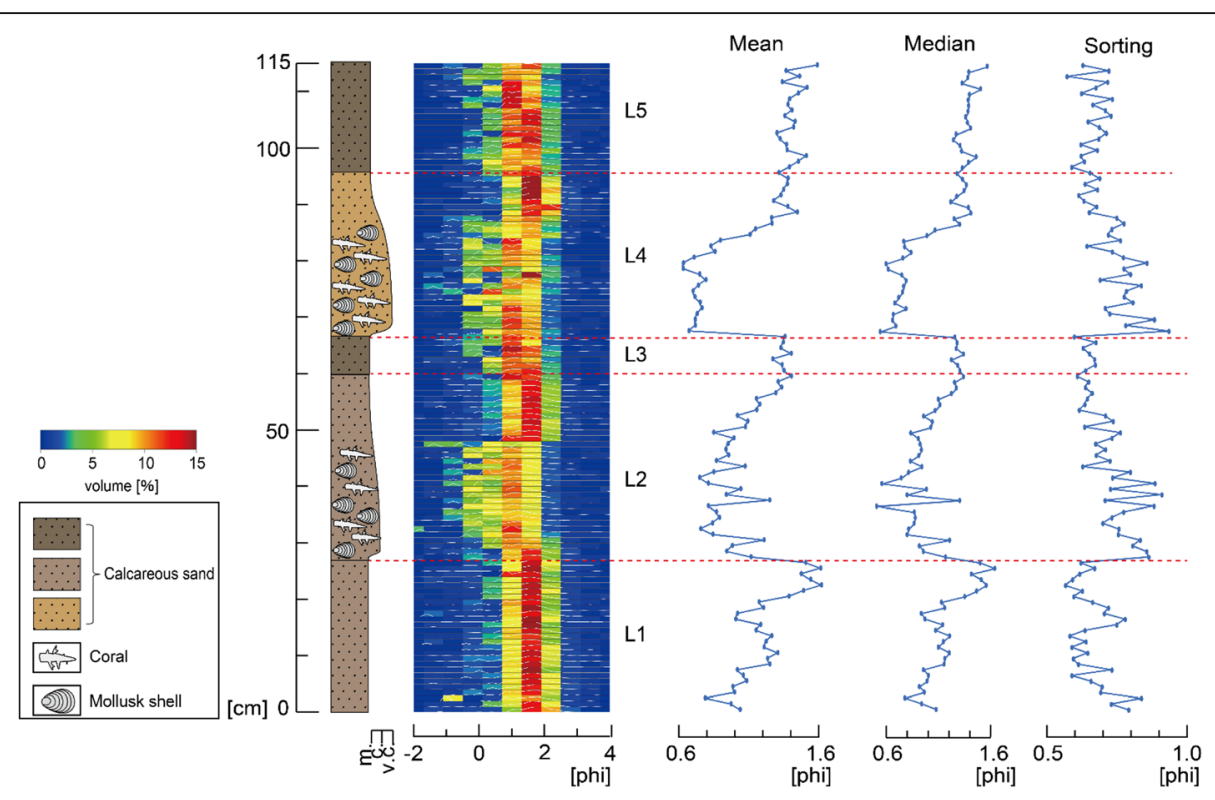

Fig. 5 Logs of lithology and grain size. Colors of the lithologic log roughly correspond to the actual color of L1 to L5 (see also Fig. S1): m, medium sand; c, coarse sand; v.c., very coarse sand. Mean and median grain sizes and sorting are shown

sedimentary structures in each layer are not clear. Most sediment constituent materials are bioclastic grainstone.

The grains of the respective layers are composed mainly of foraminiferal tests such as Calcarina sp. and Marginopora sp. with bioclasts of corals, coralline algae, bivalves, and gastropods (Fig. S1). The grains in L2 and L4 are well preserved. Several-millimeter-sized to centimeter-sized bivalves, gastropods, and corals are commonly found from the lower part of L2 and L4.

\subsection{Grain size}

Figure 5 shows vertical changes in grain size distribution together with statistical mean and median grain sizes and sorting of each layer in the trench. The grain size distribution in L1 has a mode at around 1.5 phi. It rarely contains grains of $<0$ phi or $>2.5$ phi. It also shows normal grading.

In L2, the grain size distribution changes abruptly in the middle part at $48 \mathrm{~cm}$ above the trench bottom (Fig. 5). The lower part ( $27-48 \mathrm{~cm}$ above the trench bottom) shows a bimodal grain size distribution with modes at 0 phi and 1.4 phi (Fig. 6c). The grain size distribution in the upper part (48-60 cm above the trench bottom) is rather similar to that of underlying layer 1 , with a mode around 1.5 phi (Fig. 6a, b). Mean and median grain sizes respectively show inverse grading and normal grading in the lower and upper parts of L2. Although sorting is moderate in the lower part, it decreases toward the top.

The grain size distribution of L3 and L5 has a mode at around 1.5 phi. These layers show a similar grain size distribution, which is apparent also in mean and median grain sizes and sorting. The grain size distribution of L4, which resembles that of L2, is divisible into lower and upper parts with a boundary at around $88 \mathrm{~cm}$ above the trench bottom (Fig. 5). The lower part is characterized by inverse grading with moderate sorting. However, the upper part is characterized by normal grading trend with well sorting.

Figure 7 presents a comparison of statistical values (mean vs. sorting, median vs. sorting). Mean and median grain size in L3 and L5 were 1.2-1.6 phi with sorting of $0.55-0.75$ phi. The upper parts of L2 and L4 show similar trends to those of L3 and L1. In contrast, the lower parts of L2 and L4 have different trends: mean grain size, $0.6-1.25$ phi; median grain size, $0.6-1.3$ phi; and sorting, 0.6-0.95 phi. Overall, the lower parts of L2 and L4 were coarser and poorer sorted than other layers.

\subsection{Radiocarbon dating}

We selected two coral samples for radiocarbon dating of L4: Acropora sp. 1 and Acropora sp. 2. Both samples are the least abraded among the samples taken from L4 (Fig. 8 $\mathrm{a}$ and $\mathrm{b})$. The respective calibrated dates $(2 \sigma)$ are $787-1170$ cal AD (Acropora sp. 1) and 244-632 cal AD (Acropora sp. 2) (Table 2).

We selected disarticulated marine shells of bivalve (Atactodea striata) and coral (Palauastrea ramosa) samples, both of which were the least abraded among the samples taken from L2 (Fig. 8c, d). Atactodea striata is a bivalve living in intertidal zone sand (Kondo et al. 2001). Palauastrea ramosa is a branching coral typically living around the equatorial Pacific. The respective calibrated dates $(2 \sigma)$ are 947-1281 cal AD (A. striata) and 1028$1327 \mathrm{cal}$ AD (P. ramosa) (Table 2). 


\section{a Layers 1,3 and 5}
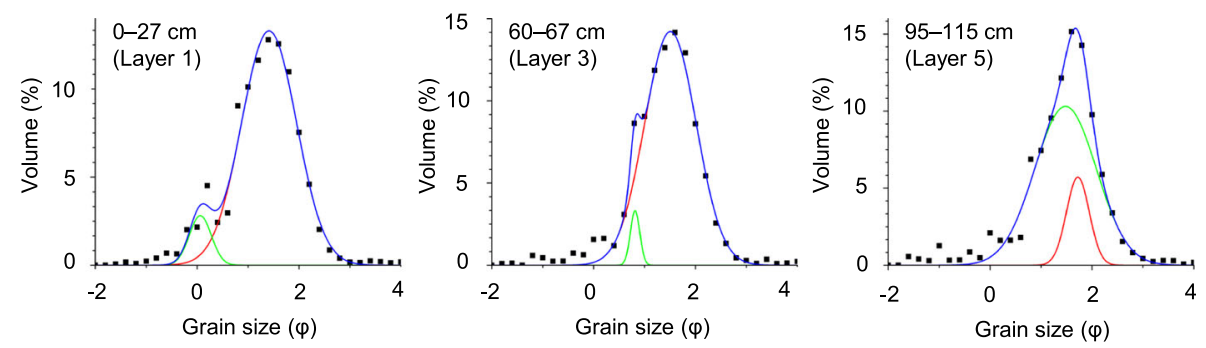

b Upper parts of layers 2 and 4
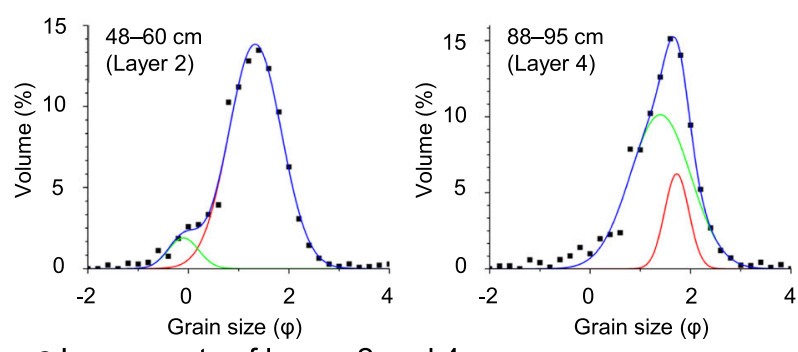

C Lower parts of layers 2 and 4
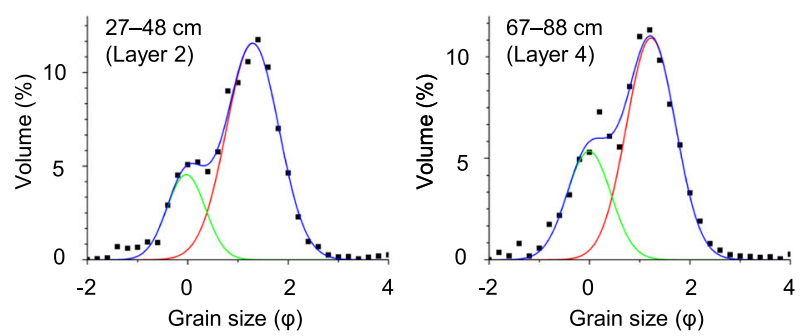

Fig. 6 Averaged grain size distribution of each layer: black squares, original data; blue lines, overall distribution against grain size; green lines, larger peaks; red lines, smaller peaks. These lines were produced by ORIGIN software

\section{Discussion}

\subsection{Identification of tsunami deposits}

Trench observations and grain size analyses clarified that sedimentary features of L2 and L4 are significantly different from other layers. For example, in the case of L4, the color (yellowish brown) is brighter than those of underlying L3 and overlying layer L5 (dark brown) (Fig. $4 \mathrm{~d}, \mathrm{S1}$ ). Moreover, the layer is divided by a sharp boundary from L3 (Fig. 4c, d). The lower part of L4 is poorersorted and coarser than L3 which is well-sorted and finer throughout the layers (Figs. 5 and 7). L4 yields abundant well-preserved bioclasts of corals, coralline algae, bivalves, and gastropods as large as pebble sized, although reworked fragments of them were also observed. These bioclasts are likely to be composed of grains originated from various sources such as a shallow part of fringing reefs (shallow lagoon and upper forereef slope), beach, or sand dunes. By contrast, L3 and L5 include fewer sand-sized bioclasts than L4 does.
Similarly, the grain composition of L2 seems clearly different from those of underlying L1 and overlying L3 (Figs. 5 and 7) in that the former includes abundant shallow marine bioclasts of corals, coralline algae, bivalves, and gastropods, although L2 is dark brown, as is L1 (Fig. 4d, S1). In addition, L2 is composed mainly of poorer-sorted and larger bioclasts than those of L1 or L3 (Figs. 5 and 7). Therefore, it is highly probable that the sediments in L2 originate from a similar environment to that of L4.

The lower parts of L2 and L4 show a bimodal grain size distribution with modes at 0 phi and 1.5 phi (Fig. 6c) and moderately sorted (sorting: 0.7-0.9 phi) (Fig. 5). In contrast, grain size distributions of the upper parts of L2 and L4 and other layers L1, L3, and L5 show a single peak (1.5 phi) (Fig. 6a, b) and are well-sorted (sorting: 0.6-0.7 phi) (Fig. 5). These differences are characterized by the amount of coarse-grained bioclasts ( -1 to 1 phi). Moreover, median (or mean) grain sizes of L2 and L4 

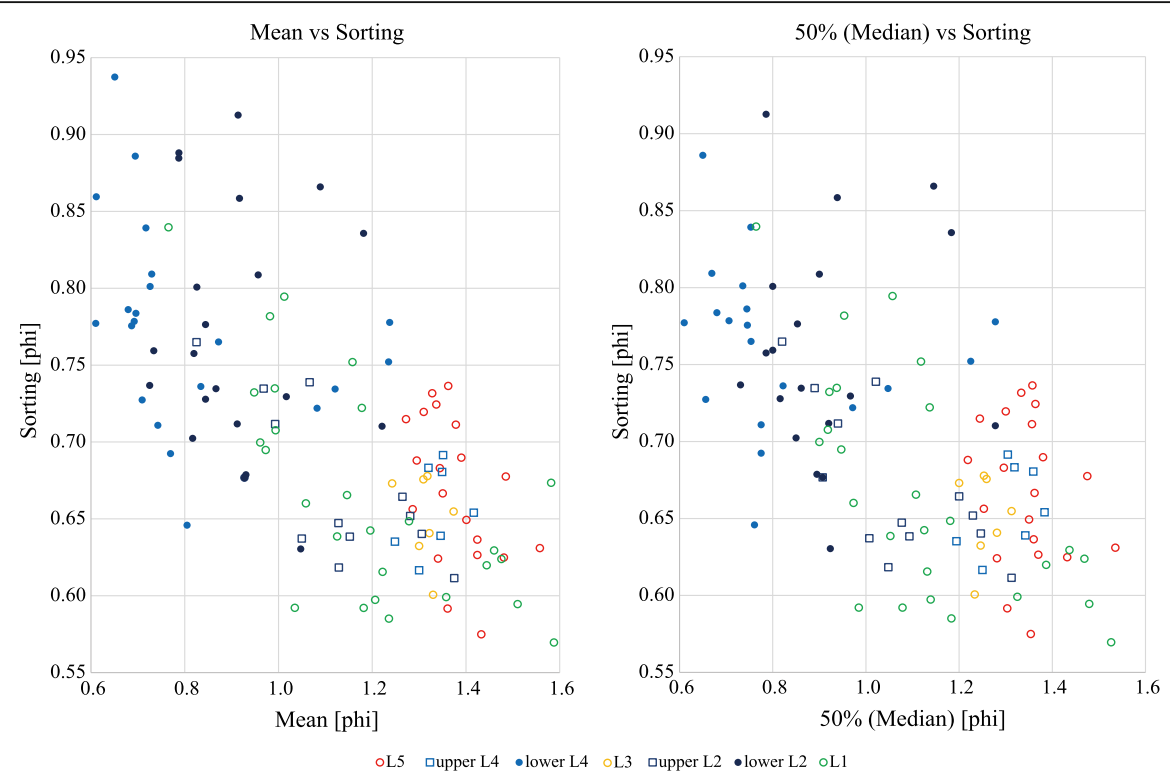

Fig. 7 Statistical values of grain size: $\mathbf{a}$, mean grain size versus sorting; $\mathbf{b}$, median grain size versus sorting

show inverse grading trends in the lower parts and then normal grading trends toward the upper parts (Fig. 5). Although a combination of inverse to normal grading trends was rarely observed in the steady sedimentary processes, it was often observed in deposits formed by high-energy water-related events such as tsunami events (e.g., Naruse et al. 2010, 2012; Moore et al. 2011). Therefore, it is highly likely that high-energy flows formed L2 and L4. Because this island has no river, flooding can be ruled out. The deposits could only have been formed by coastal waves such as tsunami and storm waves.

Our study site was located $350 \mathrm{~m}$ distant from the beach at $7 \mathrm{~m}$ amsl elevation (Fig. 3). The coastal area around the study site was surrounded by coral reefs of approximately $500 \mathrm{~m}$ width from the shoreline to the reef edge (Fig. 2). Goto et al. (2013) studied the distributions of storm wave boulders ( $>1 \mathrm{~m}$ on the long axis) on coral reefs at many islands of the Ryukyu Islands including Minna Island, which revealed that distribution of the boulders transported by the storm waves was limited to $300 \mathrm{~m}$ distance from the reef edge. Numerical simulation of storm waves at the eastern coast of Ishigaki Island (Hongo et al. 2012; Watanabe et al. 2016) demonstrated that the storm-wave velocity near the shoreline is remarkably low. Consequently, it is highly unlikely that storm waves can transport sediments up to elevation of $7 \mathrm{~m}$ amsl with more than $850 \mathrm{~m}$ distance from the reef edge. Minna Island is well known from historical records (e.g., Kato 1989; Goto et al. 2010b) to have been inundated completely by the 1771 Meiwa tsunami. Numerical modeling further suggests that effects of the 1771 Meiwa tsunami on the Miyako and Yaeyama Islands were remarkable (Goto et al. 2010a, b, 2019). This point was confirmed further by the presence of a Porites boulder of 1771 Meiwa tsunami origin at our study site at elevation of $7 \mathrm{~m}$ amsl (Kato 2000; Goto et al. 2010c). Both L2 and L4 are observed just beneath this boulder. Because the tsunami waves had sufficient energy to transport the huge boulder to the site, it is evident that the tsunami also had the capability to transport finer sand to pebble-sized grains. Consequently, L2 and L4 are regarded as having been formed by tsunami waves.

It is noteworthy that L1, L3, and L5 also consist of sandy sediments composed of bioclasts of reef organisms (Fig. S1). Their sources and sedimentation processes must be considered. Actually, the grain sizes and compositions of these three layers closely resemble those of the upper parts of L2 and L4 in that they have a single mode at 1.5 phi (Fig. 6) and include bioclasts of reef organisms. One possible origin of sands in L1, L3, and L5 might be blown sand because the grain size is generally small. However, the grain size of blown sand is well known to be finer than 1 phi (e.g., Inokuchi 1980; Goosemann et al. 2018; Lämmel et al. 2018), whereas L1, L3, and L5 all include considerable amounts of grains larger than 1 phi (Fig. 5). Therefore, blown sand is unlikely to be a source of these layers.

Alternatively, L3 and L5 might have been originally the topmost parts of L2 and L4 (equal to tsunami deposits), respectively, but they might then have been altered through a long-term pedogenic process after the tsunami events. In fact, the topmost part of the tsunami deposit is well known to be disturbed by bioturbation and reworking processes after the tsunami event. Soils originate from sand particles of the topmost part of the tsunami deposit (e.g., Goto et al. 


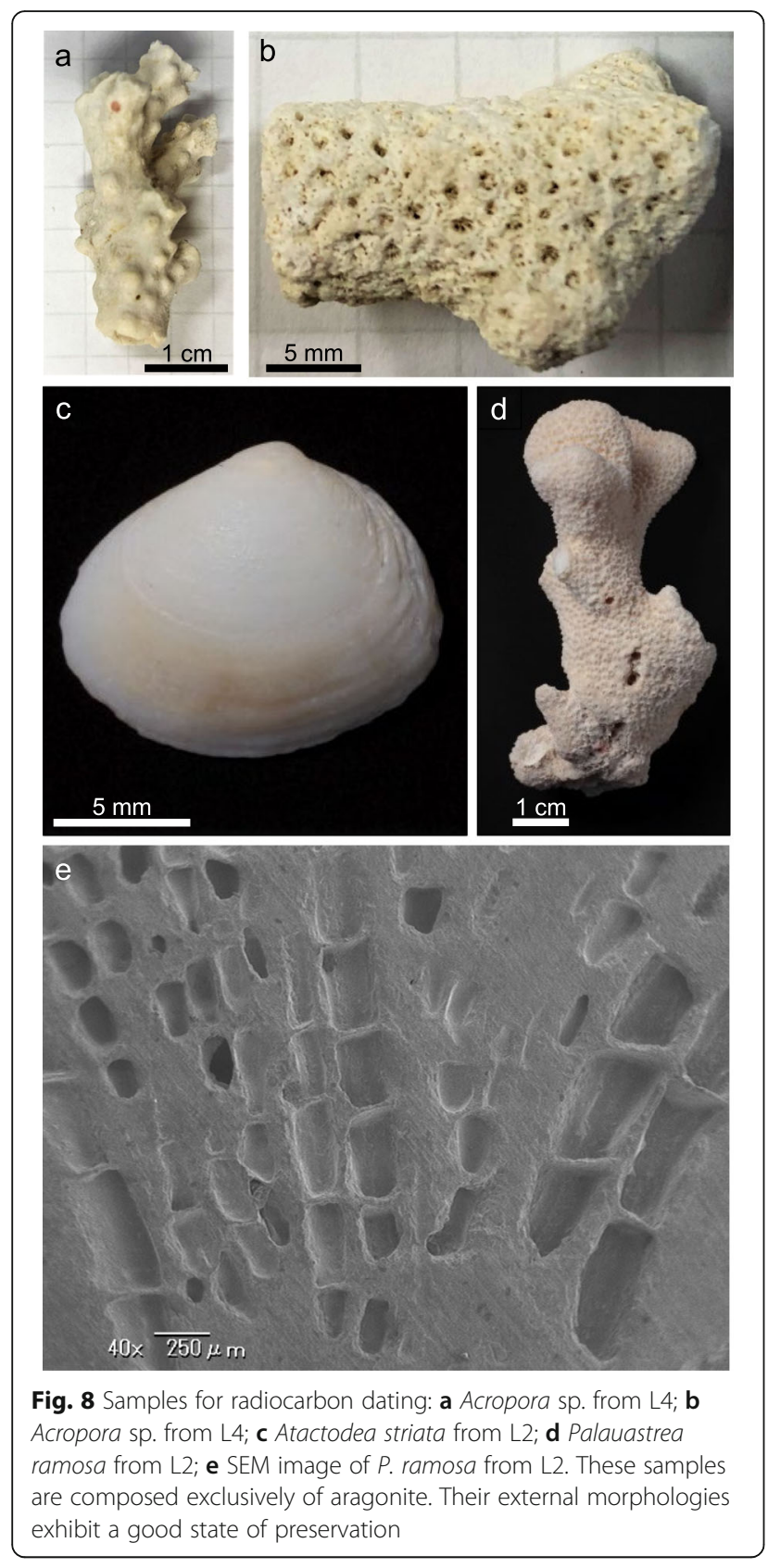

2012c; Szczuciński 2012). Considering the similarities of the grains between the upper part of L2 and L3, and the upper part of L4 and L5, respectively, this interpretation is the most likely to be true. This interpretation is further supported by the observed fact that L5 is lacking immediately beneath the 1771 tsunami boulder (Fig. 4b, c). This feature is explainable by the fact that no vegetation could have grown under the boulder. The upper part of L4 includes no coarser materials, although a minor amount of coarser materials is observable in L5. Similar grain size variation is sometimes reported also in the modern and paleotsunami deposits, and is inferred because of tsunami backwash or posttsunami local sediment reworking (e.g., Komatsubara et al. 2008; Takashimizu et al. 2012); both interpretations can be applicable to explain the grain size variation of the upper part of L4 and L5 found in our case.

If the interpretations presented above are correct, then L3 and L5 should be considered respectively as parts of L2 and L4. Therefore, we infer that two tsunami deposits exist at our study site with $40 \mathrm{~cm}$ thickness (L2 plus L3) and $48 \mathrm{~cm}$ thickness (L4 plus L5). We dug the trench with only $115 \mathrm{~cm}$ depth. For that reason, we were unable to observe the underlying deposits of $\mathrm{L} 1$. It remains uncertain whether L1 is the topmost part of an older tsunami deposit, or not.

Tsunami deposit thicknesses estimated in this study $(40 \mathrm{~cm}$ and $48 \mathrm{~cm})$ are remarkably thicker than those reported in earlier works (e.g., Szczuciński 2012; Richmond et al. 2012). Nevertheless, our study site is distant from the shoreline, probably for the following three major reasons, all of which are related to the specific sedimentary environment around Minna Island.

(1) Minna and the nearby Tarama islands were connected on the plateau at the shallow sea. Similarly to the present setting, abundant sands and gravels could have been deposited on the shelf during the past few hundred years. In addition, most of the island is rimmed by dunes. Therefore, abundant source sediments should have been available elsewhere, ranging from the shallow sea including reefs to the dunes.

(2) The island is low and flat with only a small terrestrial area. Given such a setting, tsunami waves

Table 2 Radiocarbon ages of bioclasts collected from the trench wall

\begin{tabular}{|c|c|c|c|c|c|c|}
\hline & Sample & Beta ID & Conventional radiocarbon age (years BP) & Calibrated age (cal years AD (2б)) & Median (cal years AD) & d13C (\%o) \\
\hline \multirow[t]{2}{*}{ Layer 4} & Acropora sp. 1 & 541257 & $1380 \pm 30$ & $787-1170$ & 982 & 0.68 \\
\hline & Acropora sp. 2 & 541258 & $1920 \pm 30$ & $244-632$ & 439 & 1.61 \\
\hline \multirow[t]{2}{*}{ Layer 2} & Atactodea striata & 481330 & $1260 \pm 30$ & $947-1281$ & 1112 & 1.9 \\
\hline & Palauastrea ramosa & 481331 & $1170 \pm 30$ & $1028-1327$ & 1190 & -0.5 \\
\hline
\end{tabular}


are likely to have inundated from multiple directions, as reported in the case of the 1992 Flores tsunami that struck Indonesia (Minoura et al. 1997). Based on historical records and the distribution of tsunami boulders at Tarama Island, Kawana (2004) reported that, during the 1771 Meiwa tsunami, the tsunami waves probably inundated the island from multiple directions because of wave diffraction. One can readily imagine that similar diffraction of tsunami waves occurred at Minna Island because the island shape resembles that of Tarama Island. If multidirectional inundation occurred, tsunami deposit thickness might be exaggerated several fold because of sediment transport from multiple directions.

(3) Minna Island has poor soil development. For that reason, coastal vegetation is low. Therefore, it is likely that tsunami was not attenuated during onshore inundation. Hence, the sediment transport capacity was maintained as high. This interpretation is emphasized further by the fact that even meterlong large boulders were transported at our study site (elevation of $7 \mathrm{~m}$ amsl).

Together with the three reasons above related to the specific environment of the Minna Island, grain composition constitutes an additional one. Since deposits are composed mostly of calcareous bioclasts that have lower density than silicate minerals such as quartz and feldspar; the former can be expected to have been transported easier than the latter. Calcareous bioclasts also show irregular shape; hence the rate of spacefilling of the tsunami deposit can be low. These effects can also contribute to increased total thicknesses of the tsunami deposits at our site.

\subsubsection{Age of paleotsunami at Minna Island}

Regarding the older tsunami deposit (L2 plus L3), the radiocarbon ages of the marine shell and the coral are consistent at around 920-670 cal BP (Table 2, Fig. 9). We used samples taken directly from L2 for dating. Therefore, our result should be regarded as the limiting maximum age: the actual tsunami event might be younger (but older than A.D. 1771). The samples used for radiocarbon dating retained their original mineralogy with no diagenetic alteration. Their surface textures (e.g., corallites and septa of $P$. ramosa) were well preserved (Fig. 8e). Therefore, it is most likely that they were alive immediately before the tsunami event. However, as in the case of L4, more radiocarbon results of samples from L2 must be acquired to support accurate estimation of the age of tsunami occurrence.

The calibrated age of the paleotsunami event estimated in this study $(920-670$ cal BP) partly overlaps with the age of event II $(920-620 \mathrm{cal} \mathrm{BP})$ reported by Ando et al. (2018) and event $4(1050-650 \mathrm{cal} \mathrm{BP})$ reported by Araoka et al. (2013) (Fig. 9). Ando et al. (2018) and Kitamura et al. (2018a, b) studied a sandy tsunami deposit at Ishigaki Island and inferred that event II was an event as large as the 1771 Meiwa tsunami. Therefore, one can reasonably infer that older tsunami deposits at our site were formed by the same event.

The radiocarbon ages of the two samples taken from L4 are considerably older than those of L2. A tsunami can transport sediments elsewhere from the reef, beach, and sand dune during propagation. Abundant old samples of up to 4000 years old at most can be buried in the reef sediments in the Ryukyu Islands (Yamano et al. 2001; Fujita et al. 2015). Therefore, it is likely that the samples selected for radiocarbon dating of L4 were old

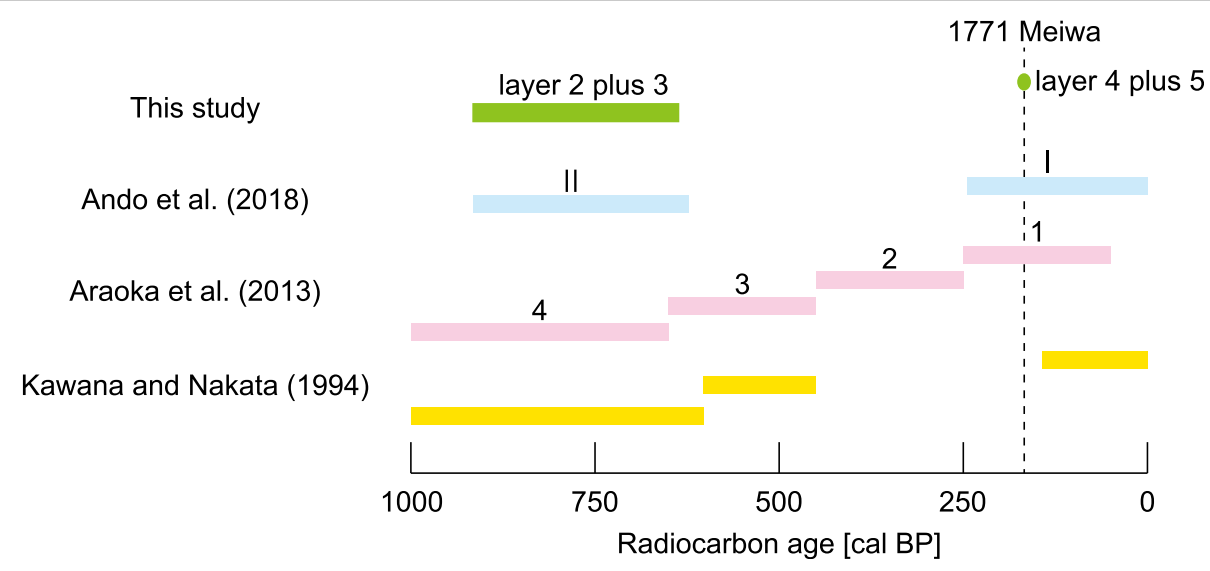

Fig. 9 Interpretation of paleotsunami histories: green lines, this study; blue lines, Ando et al. (2018); pink lines, Araoka et al. (2013); yellow lines, Kawana and Nakata (1994). The age of $L 4$ is not estimated by radiocarbon ages but by deposition order 
reef sediments: the obtained ages were much older than the actual tsunami age.

Based on our present limited dataset, one possible interpretation is that L4 was formed by the pre-1771 tsunami that might correspond to the tsunami event 2 or 3 of Araoka et al. (2013) (Fig. 9). However, it is uncertain whether these events are comparably large when measured next to the 1771 Meiwa tsunami (e.g., Araoka et al. 2013; Ando et al. 2018). Historical documents suggest that Minna Island was inundated completely by the 1771 Meiwa tsunami (Kato 1989), suggesting that the tsunami was very large at this island. Because the 1771 Meiwa tsunami boulder is deposited directly on L4 (Fig. $4 \mathrm{c}$ ), one can consider that the boulder was deposited simultaneously to the deposition of L4 plus L5. As described above, sand-sized and gravel-sized sediments are well known to be transported and deposited earlier than boulders because of their size and weight differences (Goto et al. 2012b; Yamada et al. 2014); deposition of L4 plus L5 and overlying tsunami boulders is explainable by their similar sedimentary processes. For Minna Island, we infer that the 1771 Meiwa tsunami transported sand and gravel and formed a sheet-like layer on land. Subsequently, a large Porites boulder was transported and deposited on the sandy and gravelly layer by the same tsunami. Therefore, L4 plus L5 can be interpreted stratigraphically as being of 1771 Meiwa origin. However, to confirm the origin of L4 plus L5, several radiocarbon dates must be measured in future work; then the youngest age which is taken can be regarded as representing the actual tsunami age.

It is noteworthy that our study at Minna Island was conducted at a high elevation protected by wide coral reefs. Therefore, only large tsunamis, equivalent to the 1771 Meiwa tsunami, would be able to leave a thick sand sheet. Our results suggest that at least two large tsunamis struck the Miyako Islands at possibly A.D. 1771 and during A.D. 1000-1300, although we cannot fully exclude the possibility that the upper tsunami deposit (L4 plus L5) was formed by a different tsunami that transported the 1771 tsunami boulders: one more large tsunami struck the area in the intervening period. In either case, considering our results along with those of earlier studies (Kawana and Nakata 1994; Omoto 2012; Araoka et al. 2013; Hisamatsu et al. 2014; Ando et al. 2018; Kitamura et al. 2018a, b), we conclude that large tsunamis repeatedly struck both the Miyako and Yaeyama Islands. Consequently, the hypothesis that the 1771 Meiwa tsunami was the only extraordinary event of the past (Nakaza et al. 2013) is less likely.

Results reported by Ando et al. (2018) and those obtained from the present study indicate that an interval of a tsunami event that is sufficiently powerful to lead to sandy tsunami deposit formation far inland is about 600 years. In contrast, Araoka et al. (2013) reported that the recurrence interval of a tsunami event that is sufficiently powerful to transport meter-scale boulders on the coast of the Miyako and Yaeyama Islands is about 150-400 years, which is far shorter than the interval estimated from sandy tsunami deposits. This discrepancy is probably explained by the fact that smaller tsunami boulders (1-2 m diameter) can be deposited even by small tsunamis (Araoka et al. 2013), although no possible source of small tsunami event able to transport 1-2 m-sized boulders has been discussed so far in this area. Large tsunamis forming thick sandy tsunami deposits far inland at high elevations rarely occur, which in turn suggests that the combined paleotsunami histories estimated from studies of boulders and sandy tsunami deposits will elucidate separate recurrence intervals of tsunami events of different sizes.

Several source models for the 1771 Meiwa tsunami have been proposed: intraplate earthquake plus submarine landslide (Imamura et al. 2008; Miyazawa et al. 2012), tsunami earthquake along the Ryukyu Trench (Nakamura 2009), and large slope failure near the trench axis (Okamura et al. 2018). Although our study is not conclusive on this issue, results suggest that either model can explain the repeated generation of both small and large tsunamis. Further careful paleotsunami research must be conducted with numerical modeling to constrain these tsunami source models.

\subsubsection{Tsunami as a geomorphic agent of small reef island}

Large tsunami waves can drastically change the coastal topography of small islands with circumjacent reefs (Kench and Brander 2006; Kench et al. 2008; Paris et al. 2009). As the GPR profile of our site shows (Fig. 3b), no strong reflector exists from the ground surface (approximately $7 \mathrm{~m}$ amsl elevation) to $0 \mathrm{~m}$ amsl at our trench site except for a strong reflector at $50 \mathrm{~cm}$ depth, which corresponds to the base of $\mathrm{L} 4$. This result implies that the basement Ryukyu Group might be located below elevation of $0 \mathrm{~m}$ amsl and that sediments of about $7 \mathrm{~m}$ thickness from the ground surface are probably composed of sand. Indeed, Yazaki (1977) pointed out that the dune sand thickness at Minna Island is at least $7 \mathrm{~m}$.

The coral reefs at Minna Island were probably constituted in their present form around 5000 years ago (Omoto 2004). Here, we assume that sufficient sediments exist at the source region among tsunami events. This assumption is probably valid because approximately 250 years have passed since the 1771 tsunami and because the present sediment production in the source region at the beach and the reefs is very high at this island. Therefore, a-few-hundred-year tsunami interval is sufficiently long for the accumulation of thick sediments in the source region. If one assumes that large tsunamis 
struck repeatedly during this period with a 600-year interval, then eight or more tsunamis might have inundated Minna Island during the last 5000 years. If each tsunami formed sediments with $40-50 \mathrm{~cm}$ thickness, then the sediments would reach 3.2-4.0 m thickness. Although many other processes such as tsunami erosion, crustal movement, relative sea level change, dune formation, blown sand, and pedogenic processes should also be considered, we infer that tsunami waves can be an important geomorphic agent for the formation of reefsurrounded small islands such as Minna Island in this region, where tsunamis frequently exert their effects in short intervals.

\section{Conclusions}

We discovered two sandy tsunami deposits on Minna Island. The younger tsunami deposit is likely to have been formed by the 1771 Meiwa tsunami, whereas the older one was probably formed by a tsunami at around 920 $670 \mathrm{cal}$ BP. However, several more samples must be dated to provide more accurate tsunami age assessment. Our results indicate that at least two tsunamis (the 1771 Meiwa tsunami and an older one comparable to the 1771 event) are likely to have hit not only the Yaeyama Islands but also the Miyako Islands during the last 1000 years. This finding presents important implications elucidating the paleotsunami history of the Miyako and Yaeyama Islands, whether large tsunamis occurred periodically or not. Indeed, this region shows high risk of low-frequent but powerful tsunami events.

It is also likely that the tsunami waves repeatedly transported and deposited thick sands on land. In fact, these sedimentation events might have contributed to the geomorphological development of Minna Island in the late Quaternary. Therefore, we infer that tsunami waves can be one important agent forming and modifying the geomorphology of small reef-encircled islands.

\section{Supplementary information}

Supplementary information accompanies this paper at https://doi.org/10. 1186/s40645-020-00365-9.

Additional file 1: Fig. S1. Close-up photographs of sands in $L 1-L 5$

\section{Abbreviations}

amsl: above the mean sea level; GPR: Ground-Penetrating Rader; XRD: X-Ray Diffraction; SEM: Scanning Electron Microscopy

\section{Acknowledgments}

We thank an area land owner for his kind help with our study and thank $\mathrm{K}$. Miyagi for his cooperation with our field survey. We also thank D. Yamaguchi and S. Sato for identification of coral and molluscan samples and T. Ishizawa for his advice of the radiocarbon dating. We also thank K. Ikehara and two anonymous reviewers for their valuable suggestions and comments.

\section{Authors' contributions}

$\mathrm{RF}, \mathrm{KG}, \mathrm{Yl}$, and TA conducted field surveys, collected samples and data, and participated in discussion during the research. RF mainly performed experiments and wrote the manuscript. KG proposed the study topic and conceived and designed the study. YI conducted identification of carbonate samples and assisted in the interpretation of XRD/SEM results. TA provided geological information of Minna Island and conducted statistical analysis of grain size. All authors read and approved the final manuscript.

\section{Funding}

This research was partly supported by research funding from JSPS KAKENHI Grant Numbers (JP15H05220) and by the Ministry of Education, Culture, Sports Science and Technology (MEXT) of Japan, under its The Second Earthquake and Volcano Hazards Observation and Research Program (Earthquake and Volcano Hazard Reduction Research).

\section{Availability of data and materials}

Please contact the corresponding author with data requests.

\section{Competing interests}

The authors declare that they have no competing interest.

\section{Author details}

${ }^{1}$ Department of Earth Science, Graduate School of Tohoku University, Aramaki-Aza-aoba, 6-3, Aoba-ku, Sendai 980-8578, Japan. ${ }^{2}$ International Research Institute of Disaster Science, Tohoku University, Aramaki-aza-Aoba, 468-1, Aoba-ku, Sendai 980-8572, Japan. ${ }^{3}$ Department of Earth and Planetary Science, The University of Tokyo, 7-3-1, Hongo, Bunkyo-ku, Tokyo 113-0033, Japan. ${ }^{4}$ Geological Survey of Japan, National Institute of Advanced Industrial Science and Technology, Central 7, Higashi 1-1-1, Tsukuba 305-8567, Japan.

Received: 29 January 2020 Accepted: 20 August 2020

Published online: 23 September 2020

\section{References}

Ando M, Kitamura A, Tu Y, Ohashi Y, Imai T, Nakamura M, Ikuta R, Miyairi Y, Yokoyama Y, Shishikura M (2018) Source of high tsunamis along the southernmost Ryukyu trench inferred from tsunami stratigraphy. Tectonophysics 722:265-276

Araoka D, Inoue M, Suzuki A, Yokoyama Y, Edwards H, Cheng H, Matsuzaki H, Kan H, Shikazono N, Kawahata H (2010) Historic 1771 Meiwa tsunami confirmed by high-resolution U/Th dating of massive Porites coral boulders at Ishigaki Island in the Ryukyus, Japan. Geochem Geophys Geosyst 11. Q06014, https:// doi.org/10.1029/2009GC002893

Araoka D, Yokoyama Y, Suzuki A, Goto K, Miyagi K, Miyazawa K, Matsuzaki H, Kawahata H (2013) Tsunami recurrence revealed by Porites coral boulders in the southern Ryukyu Islands, Japan. Geology 41:919-922. https://doi.org/10. $1130 / \mathrm{G} 34415.1$

Folk RL (1966) A review of grain-size parameters. Sedimentology 6:73-93. https:// doi.org/10.1111/j.1365-3091.1966.tb01572.x

Fujita K, Asami R, Takayanagi H, Iryu Y (2015) Carbonate sedimentation in seagrass beds on Ishigaki-jima, Ryukyu Islands, southwestern Japan. Island Arc 24:263-279. https://doi.org/10.1111/iar.12112

Goosemann EA, Catling DC, Som SM, Altermann W, Buick R (2018) Eolianite grain size distributions as a proxy for large changes in planetary atmospheric density. J Geophys Res 123:2506-2526. https://doi.org/10.1029/2018JE005723

Goto K, Hongo C, Watanabe M, Miyazawa K, Hisamatsu A (2019) Large tsunamis reset the growth of massive corals. Prog Earth Planet Sci 6:14. https://doi.org/ 10.1186/s40645-019-0265-2

Goto K, Kawana T, Imamura F (2010a) Historical and geological evidence of boulders deposited by tsunamis, southern Ryukyu Islands, Japan. Earth Sci Rev 102:77-99. https://doi.org/10.1016/j.earscirev.2010.06.005

Goto K, Miyagi K, Imamura F (2013) Localized tsunamigenic earthquakes inferred from preferential distribution of coastal boulders on Ryukyu Islands, Japan. Geology 41:1139-1142. https://doi.org/10.1130/G34823.1

Goto K, Miyagi K, Kawamata H, Imamura F (2010b) Discrimination of boulders deposited by tsunamis and storm waves at Ishigaki Island, Japan. Mar Geol 269:34-45. https://doi.org/10.1016/j.margeo.2009.12.004

Goto K, Miyagi K, Kawana T (2010c) Discovery of the large Porites boulders by the 1771 tsunami at Tarama and Minna Islands, Japan. Res Rep Tsunami Eng 27:97-102 
Goto K, Miyazawa K, Adaniya A, Kakihana S, Kugai M, Shimabukuro A, Masaki J, Matsushima S, Miyagi K (2012a) Reconsideration of the run-up height of the 1771 Meiwa tsunami II - Sakishima Islands. Res Rep Tsunami Eng 29:129-146

Goto K, Sugawara D, Ikema S, Miyagi T (2012b) Sedimentary processes associated with sand and boulder deposits formed by the 2011 Tohoku-oki tsunami at Sabusawa Island, Japan. Sediment Geol 282:188-198. https://doi.org/10.1016/ j.sedgeo.2012.03.017

Goto K, Takahashi J, Fujino S (2012C) Variations in the 2004 Indian Ocean tsunami deposits thickness and their preservation potential, southwestern Thailand. Earth Planet and Space 64:923-930. https://doi.org/10.5047/eps.2011.08.019

Hirabayashi S, Yokoyama Y, Suzuki A, Miyairi Y, Aze T (2017) Short-term fluctuations in regional radiocarbon reservoir age recorded in coral skeletons from the Ryukyu Islands in the North-Western Pacific. J Quat Sci 32:1-6. https://doi.org/10.1002/jqs.2923

Hisamatsu S, Goto K, Imamura F (2014) Local paleo-tsunami size evaluation using numerical modelling for boulder transport at Ishigaki Island, southern Japan. Episodes 37:265-276. https://doi.org/10.18814/epiiugs/2014/v37i4/006

Hongo C, Kawamata H, Goto K (2012) Catastrophic impact of typhoon waves on coral communities in the Ryukyu Islands under global warming. J Geophys Res 117:G02029. https://doi.org/10.18814/epiiugs/2014/v37i4/006

Imamura F, Goto K, Okubo S (2008) A numerical model for the transport of a boulder by tsunami. J Geophys Res 113:C01008. https://doi.org/10.1029/ 2007JC004170

Inokuchi M (1980) Grain size distribution of sediment in transit. Geophys Rev Japan 53:769-780. https://doi.org/10.4157/gri.53.769

Inoue T, Goto K, Nishimura Y, Watanabe M, lijima Y, Sugawara D (2017) Paleotsunami history along the northern Japan trench: evidence from Noda Village, northern Sanriku coast, Japan. Prog Earth Planet Sci 4:42. https://doi. org/10.1186/s40645-017-0158-1

Iryu Y, Matsuda H, Machiyama H, Piller WE, Quinn TM, Mutti M (2006) An introductory perspective on the COREF project. Island Arc 15:393-406. https://doi.org/10.1111/j.1440-1738.2006.00537.x

Ishimura D, Miyauchi T (2015) Historical and paleo-tsunami deposits during the last 4000 years and their correlation with historical tsunami events in Koyadori on the Sanriku coast, northeastern Japan. Prog Earth Planet Sci 2:16. https://doi.org/10.1186/s40645-015-0047-4

Kato Y (1989) Yaeyama seismic tsunami (1771) in the Miyako Islands recorded in the newly found archives "Otoiai-gaki". Bull Coll Sci Univ Ryukyus 47:153-158

Kato Y (2000) Tsunamiisi stones at Miyako-Minna-Jima Island, the Ryukyu Islands. Hist Earthquakes 16:203-205

Kawana T (1986) Holocene crustal movement in and around the Sekisei Lagoon in Okinawa Prefecture, Japan: Earth Monthly 9:129-134. (in Japanese, original title translated)

Kawana T (1989) Quaternary crustal movement in the Ryukyu Islands. Earth Monthly 11:618-630. (in Japanese, original title translated)

Kawana T (2004) Holocene tsunami boulders in Tarama and beach rock in Kur Islands, the Ryukyus, Japan: implication of diffraction of waves. Bull Faculty Edu Univ Ryukyus 64:1-7

Kawana T, Nakata T (1994) Timing of late Holocene tsunamis originated around the southern Ryukyu Islands, Japan, deduced from coralline tsunami deposits. J Geol Soc Japan 103:352-376. https://doi.org/10.5026/jgeography. 103.4_352

Kench PS, Brander RW (2006) Wave processes on coral reef flats: implication for reef geomorphology using Australian case studies. J Coastal Res 221:209_ 224. https://doi.org/10.2112/05A-0016.1

Kench PS, Nichol SL, Smithers SG, McLean RF, Brander RW (2008) Tsunami as agents of geomorphic change in mid-ocean reef islands. Geomorph 95:361-383

Kitamura A (2016) Examination of the largest-possible tsunamis (level 2 tsunami) generated along the Nankai and Suruga troughs during the past 4000 years based on studies of tsunami deposits from the 2011 Tohoku-oki tsunami. Prog Earth Planet Sci 3:12 https://doi.org/10.1186/s40645-016-0092-7

Kitamura A, Ito M, Ikuta R, Ikeda M (2018a) Using molluscan assemblage from paleotsunami deposits to evaluate the influence of topography on the magnitude of late Holocene mega-tsunamis on Ishigaki Island, Japan. Prog Earth Planet Sci:41. https://doi.org/10.1186/s40645-018-0200-y

Kitamura A, Ito M, Sakai S, Yokoyama Y, Miyairi Y (2018b) Identification of tsunami deposits using a combination of radiometric dating and oxygen-isotope profiles of articulated bivalves. Mar Geol 403:57-61. https://doi.org/10.1016/ margeo.2018.04.003

Komatsubara J, Fujiwara O, Takada K, Sawai Y, Aung TT, Kamataki T (2008) Historical tsunamis and storms recorded in a coastal lowland, Shizuoka prefecture, along the Pacific coast of Japan. Sedimentol 55:1703-1716. https://doi.org/10.1111/j.1365-3091.2008.00964.x

Kondo Y, Yokogawa K, Shiratsuchi T (2001) Substrate preferences and burrowing ability of Donacidae and Mesodesmatidae (Bivalvia) on beaches of Southwest Japan. Venus 60(1/2):57-69. doi: 10.18941/venus.60.1-2_57

Konishi K, Matsuda S (1980) Relative fall of sea level within the past 3000 year. Trans Proceed Paleontol Soc Japan. NS 117:243-246. doi: https://doi.org/10. 14825/prpsj1951.1980.117-243

Kugai M (2011) Foraminifera sedimentation discovered in Tomori-Motojima and Sunagawa-Motojima. Bull Miyakojima City Mus 15:65-75

Lämmel M, Meiwald A, Yizhaq H, Tsoar H, Katra I, Kroy K (2018) Aeolian sand sorting and megaripple formation. Nature Phys 14:759-765. https://doi.org/ 10.1038/s41567-018-0106-z

Minoura K, Imamura F, Sugawara D, Kono Y, Iwashita T (2001) The 869 Jogan tsunami deposit and recurrence interval of large-scale tsunami on the Pacific coast of Northeast Japan. J Nat Dis Sci 23:83-88

Minoura K, Imamura F, Takahashi T, Shuto N (1997) Sequence of sedimentation processes caused by the 1992 Flores tsunami: evidence from Babi Island. Geology 25:523-526

Miyazawa K, Goto K, Imamura F (2012) Re-evaluation of the 1771 Meiwa tsunami source model, southern Ryukyu Islands, Japan. In: Yamada Y, Kawamura K, Ikehara K, Ogawa Y, Urgeles R, Mosher D, Chaytor J, Strasser M (eds) Advances in natural and technological hazards research, submarine mass movements and their consequences, vol 31. Springer, Heidelberg, pp 497506. https://doi.org/10.1007/978-94-007-2162-3_44

Moore A, Goff J, McAdoo BG, Fritz HM, Gusman A, Kalligeris N, Kalsum K, Susanto A, Suteja D, Synolakis CE (2011) Sedimentary deposits from the 17 July 2006 western Java tsunami, Indonesia: use of grain size analyses to assess tsunami flow depth, speed, and traction carpet characteristics. Pure Appl Geophys 168:1951-1961

Nakamura M (2009) Fault model of the 1771 Yaeyama earthquake along the Ryukyu trench estimated from the devastating tsunami. Geophys Res Lett 36: L19307. https://doi.org/10.1029/2009GL039730

Nakaza E, Iribe T, Tokuhisa R, Miyazato N, Inagaki K (2013) Historical and prehistorical tsunamis in the Ryukyu Islands estimated through tsunami depositions. J Japan Soc Civil Eng B3 (Ocean Eng) 69:515-520. https://doi. org/10.2208/jscejoe.69.I_515

Naruse H (2005) Usage and advantages of an application program "STube" for settling tube grain-size analysis. J Sedim Soc Japan 62:55-61. https://doi.org/ 10.4096/jssj1995.62.55

Naruse H, Arai K, Matsumoto D, Takahashi H, Yamashita S, Tanaka G, Murayama M (2012) Sedimentary features observed in the tsunami deposits at Rikuzentakata City. Sediment Geol 282:199-215 https://doi.org/10.1016/j. sedgeo.2012.08.012

Naruse H, Fujino S, Suphawajruksakul A, Jarupongsakul T (2010) Features and formation processes of multiple deposition layers from the 2004 Indian Ocean tsunami at ban Nam Kem, southern Thailand. Island Arc 19:399-411. https://doi.org/10.1111/j.1440-1738.2010.00732.x

Okamura Y, Nishizawa Y, Fujii Y, Yanagisawa H (2018) Accretionary prism collapse: a new hypothesis on the source of the 1771 giant tsunami in the Ryukyu arc SW Japan. Sci Rep 8:13620. https://doi.org/10.1038/s41598-018-31956-8

Okinawa Prefecture Gusukube Town Board of Education (2004) Rep. TomoriMotojima remains. Rep. Tomori-Motojima remains, 78p

Omoto K (2004) Radiocarbon ages and isotope fractionations of beachrock samples collected from the Nansei Islands, southernwest Japan. Radiocarbon 46:539-550. https://doi.org/10.1017/S0033822200035591

Omoto K (2012) Distribution of coral boulders beached by huge tsunamis and calibrated radiocarbon ages of fossil Porites sp. of Maibahabama, SE of Miyako Island, Okinawa prefecture. J Geography (Chigaku Zasshi) 121:1043-1051

Paris R, Wassmer P, Sartohadi J, Lavigne F, Barthomeuf B, Desgages E, Grancher $D$, Baumert $P$, Vautier F, Brunstein D, Gomez C (2009) Tsunamis as geomorphic crises: lessons from the December 26, 2004 tsunami in Lhok Nga, West Banda Aceh (Sumatra, Indonesia). Geomorphology 104:59-72. https://doi.org/10.1016/j.geomorph.2008.05.040

Pirazzoli PA, Kawana T, Montaggioni LF (1984) Late Holocene sea-level changes in Tarama Island, the Ryukyus, Japan. Ear Sci (Chikyu Kagaku) 38:113-118. doi: https://doi.org/10.15080/agcjchikyukagaku.38.2_113

Reimer PJ, Bard E, Bayliss A, Beck JW, Blackwell PG, Bronk Ramsey C, Buck CE, Cheng $H$, Edwards RL, Friedrich M, Grootes PM, Guilderson TP, Haflidason H, Hajdas I, Hatté C, Heaton TJ, Hoffmann DL, Hogg AG, Hughen KA, Kaiser KF, Kromer B, Manning SW, Niu M, Reimer RW, Richards DA, Scott EM, Southon 
JR, Staff RA, Turney CSM, van der Plicht J (2013) IntCal13 and Marine13 radiocarbon age calibration curves $0-50,000$ years cal BP. Radiocarbon 55 1869-1887

Richmond B, Szczuciński W, Chaqué-Goff C, Goto K, Sugawara D, Witter R, Tappin DR, Jaffe B, Fujino S, Nishimura Y, Goff J (2012) Erosion, deposition and landscape change on the Sendai coastal plain, Japan, resulting from the march 11, 2011 Tohoku-oki tsunami. Sediment Geol 282:27-39

Sato T, Nakamura N, Goto K, Kumagai H, Nagahama H, Minoura K (2014) Paleomagnetism reveals the emplacement age of tsunamigenic coral boulders in Ishigaki Island, Japan. Geology 42:603-606. https://doi.org/10. $1130 / \mathrm{G} 35366.1$

Sawai Y (2012) Study on paleotsunami deposits in geologic stratum. J Geol Soc Japan 118:535-558. https://doi.org/10.5575/geosoc.2012.0063

Shimada Y, Fujino S, Sawai Y, Koichiro T, Matsumoto D, Momohara A, Saito-Kato M, Yamada M, Hirayama E, Suzuki T, Chagué C (2019) Geological record of prehistoric tsunamis in Mugi town, facing the Nankai trough, western Japan. Prog Earth Planet Sci 6:37. https://doi.org/10.1186/s40645-019-0279-9

Stuiver M, Reimer PJ (1993) Extended ${ }^{14} \mathrm{C}$ data base and revised CALIB $3.0{ }^{14} \mathrm{C}$ age calibration program. Radiocarbon 35:215-230

Stuiver M, Reimer PJ, Reimer RW (2020) CALIB 7.1 [WWW program] at http://calib. org, accessed 2020-5-28

Szczuciński W (2012) The post-depositinal changes of the onshore 2004 tsunami deposits on the Andaman Sea coast of Thailand. Nat Hazards (Dordr) 60:115133. https://doi.org/10.1007/s11069-011-9956-8

Takashimizu Y, Urabe A, Suzuki K, Sato Y (2012) Deposition by the 2011 Tohokuoki tsunami on coastal lowland controlled by beach ridges near Sendai, Japan. Sediment Geol 282:124-141

Takeda H, Goto K, Goff J, Matsumoto H, Sugawara D (2018) Could tsunami risk be underestimated using core-based reconstructions? Lessons from ground penetrating radar. Earth Surf Process Land 43:808-816. https://doi.org/10. 1002/esp.4282

Watanabe M, Goto K, Imamura F, Hongo C (2016) Numerical identification of tsunami boulders and estimation of local tsunami size at Irabuma reef of Ishigaki Island, Japan. Island Arc 25:316-332. https://doi.org/10.1111/iar.12115

Yamada M, Fujino S, Goto K (2014) Deposition of sediments of diverse sizes by the 2011 Tohoku-oki tsunami at Miyako City, Japan. Mar Geol 358:67-78. https://doi.org/10.1016/j.margeo.2014.05.019

Yamamoto M (2008) Trace of earthquake and tsunami in Ishigaki Island, Yaeyama archipelago. Archaeol J 577:9-14

Yamamoto M, Souda T, Kawana T (2009) Trace of earthquake and tsunami in Ishigaki Island. Archeol Q 106:91-92

Yamano H, Kayanne H, Yonekura N (2001) Anatomy of a modern coral reef flat: a recorder of storms and uplift in the late Holocene. J Sedim Res 71:295-304. https://doi.org/10.1306/082900710295

Yawsangratt S, Szczuciński W, Chaimanee N, Jadgodziński R, Lorenc S, Chatprasert S, Saisuttichai D, Tepsuwan T (2009) Depositional effects of 2004 tsunami and hypothetical paleotsunami near Thap Lamu navy base in Phang Nga Province, Thailand. Polish J Environ Stud 18:17-23

Yazaki K (1977) Geology of the Taramashima District. Quadangle Series, Scale 1: 50,000, Miyako-jima (19) no. 5, Geological Survey of Japan, Kawasaki

\section{Publisher's Note}

Springer Nature remains neutral with regard to jurisdictional claims in published maps and institutional affiliations.

\section{Submit your manuscript to a SpringerOpen ${ }^{\circ}$ journal and benefit from:}

- Convenient online submission

- Rigorous peer review

- Open access: articles freely available online

- High visibility within the field

- Retaining the copyright to your article

Submit your next manuscript at $\boldsymbol{\nabla}$ springeropen.com 